\title{
肩腱板広範囲断裂に対する広背筋移行術の経験
}

\author{
小郡第一総合病院整形外科 \\ 川上 不二夫・土 井 一 輝 \\ 桑 田 憲 幸・服 部 泰 典 \\ 大塚健・大 野 晃 靖
}

\section{Experience of Latissimus Dorsi Transfer for Massive Tears of Rotator-Cuff}

\author{
Fujio Kawakami, Kazuteru Doi, Noriyuki Kuwata, Yasunori Hattori, \\ Ken Otuka and Teruyasu Ono \\ Department of Orthopaedic Surgery, Ogori Daiichi General Hospital, Yamaguchi, Japan
}

We treated 7 shoulders in 7 patients with massive tears of rorator-cuff by the transfer of the latissumus dorsi. They consists of 4 men and 3 women. Their average age was 60 years and the average follow - up was 13 months (10-19).

Clinical results were evaluated by R.O.M., complications, the latest complaints, and isokinetic muscle strength measured by the Kin-Com machine. Electromyography and MR imaging were performed on the transferred latissmus dorsi.

Active forward flexion improved from a preoperative average of $95^{\circ}$ to a postoperative average of $165^{\circ}$. Early complications include shoulder-hand syndrom in 2 shoulders and superficial infection in 1. Recovery of muscle strength was fair in the anterior forward flexion in 3 shoulders. EMG studies revealed the transferred latissimus dorsi were not functioning in the forward flexion and external rotation with the arm at $90^{\circ}$ abduction. Rerupture was found in 2 shoulders in the MR image.

We conclude that latissimus dorsi transfer can be effective for massive tears of rotator-cuff. But as the muscles show no switching of their functional mechanism, this procedure is not recommended for young and manual workers.

Key words : Massive Tears of Rotator-Cuff (腱板広範囲断裂), Latissimus Dorsi Transfer（広背筋 移行術), Clinical Results（術後成績）

はじめに

上腕骨頭表面を被覆することができない程の腱板広 範囲断裂に対して, 棘上筋進展術, 腱移植術あるいは 修復を行わずデブリードメントのみを行う方法などが ある. 当院では広背筋移行術を行っており短期成績に つき検討を加えたので報告する。
対象及び方法

症例はMcLaughlin 法で骨頭被覆ができず広背筋 移行術を追加した 7 症例 7 肩関節である. 男性 4 例, 女性 3 例. 48 歳加 74 歳, 平均 60 歳. 術後経過観 察期間は平均 13 ヶ月ですべて利き手側である．腱疟 痕部を除去, 退縮した腱を advance した後の欠損部 の大きさは上肢下垂位で $1.5 \times 1.5 \mathrm{~cm}$ から $2.5 \times 2 \mathrm{~cm}$ 
であった，腱板断裂は棘上筋 7 腱，棘下筋 6 腱，肩甲 下筋 2 腱, biceps long head 3 腱であった。後療法 は肩拳上装置で 4 週間固定， 6 週後にフリーとした。

各症例で関節可動域（以下 ROM），日整会肩治療 判定基準（以下 JOA score）, 合併症亡現在の愁訴, 手術側及び健側の広背筋筋電図，KIN-COMによる 筋力評価，またMRIによる再断裂の検討を行った。

\section{結果}

前方拳上術前 95 度が術後 165 度に改善, 内旋は術 前第 12 胸椎棘突起が第 2 腰椎棘突起に悪化していた。 前方拳上の改善と内旋の増悪には統計的有意差があっ た. JOA score は術前 53 点が 87 点に改善した（図 1). 術後 3 ヶ月以内の早期合併症は肩手症候群 2 例, 表在性感染 1 例であった．現在の愁訴は前方拳上困難 が 4 例, 拳上位作業が困難が 3 例あり, 結果として前 方拳上筋力が不十分であった。

局関節の各運動方向における広背筋の筋電図波形に おいて motor unit potential の最大振幅を計測した。 広背筋の本来の収縮方向である伸展, 内転内旋におい て最大振幅は健側に対し減少していたが統計的有意差
は認められなかった（図 2)。前方拳上，外旋動作に おいて motor unit potential が羿められたのは 2 症 例，外転外旋では 3 症例のみであり，いずれあ最大振 幅は 50 から $300 \mu \mathrm{V}$ 程度で有意な振幅ではなかった。

$\mathrm{KIN}-\mathrm{COM}$ による筋力評価で, 求心性収樎の手術 側ピークトルクと健側比はそれぞれ拳上 $15 \mathrm{Nm}$, 健

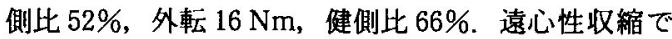
は拳上 $19 \mathrm{Nm}$, 健側比 $42 \%$, 外転 $15 \mathrm{Nm}$, 健側比 38 \%であった．外転筋力に比べ前方拳上筋力が特に優れ ているとはいえなかった. MRI は oblique sagittal, oblique coronal, sagittal の 3 方向で撮影し，骨頭 直上部における腱板の状態を評価した。連続性があり 厚いのは 2 例，連続性があるが薄いのは 3 例，腱板を 越えて関節液の信号が連続し再断裂と診断したのは 2 例 29\%であった。1 1 例は再断裂が存在しても JOA score は 90 点と良好であった。

症

例

68 歳男性. 平成 9 年 3 月, 広背筋移行術を施行し た. 術後 15 ヶ月の現在, 重労働時に痛みあり， $1 \mathrm{~kg}$ 鉄アレイ水平保持 7 秒, 内旋は第 2 腰椎棘突起で
- JOAscore -

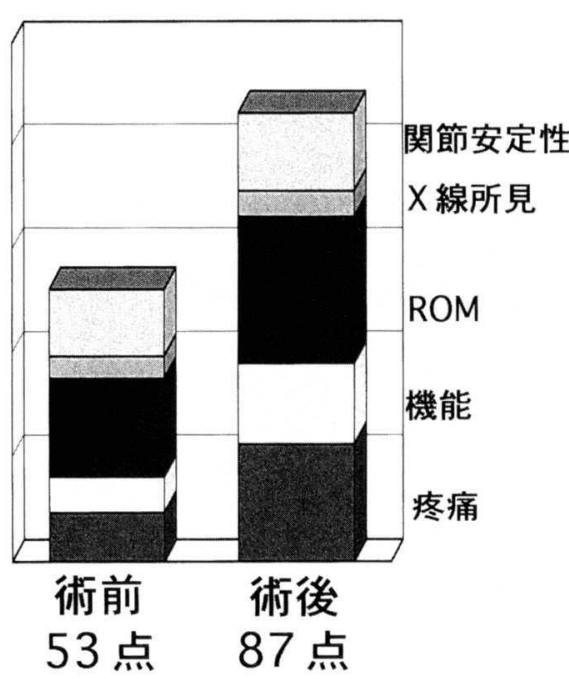

- R OM -

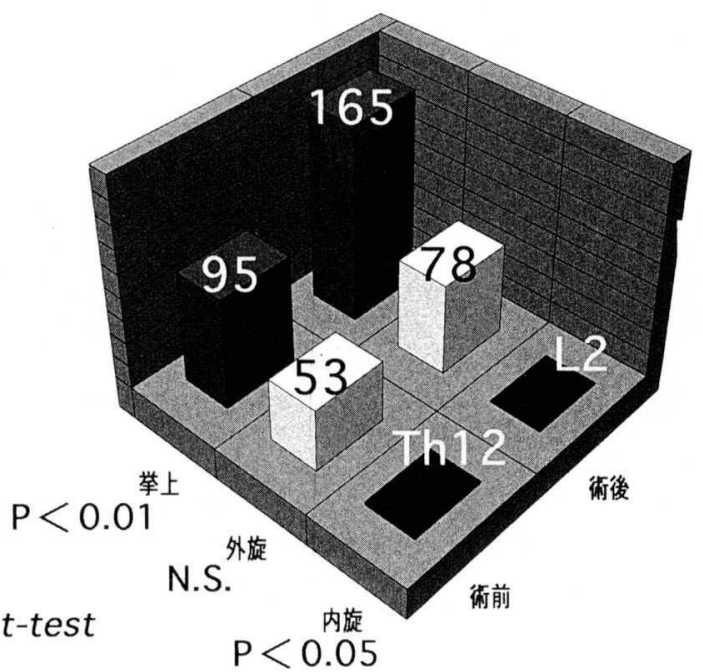

図 1 右 : ROM は術前拳上平均 95 度が術後拳上 165 度に改善 $(\mathrm{p}<0.01)$. 術前内旋平均第 12 胸椎棘突起加ら術後は第 4 腰椎棘乫起八覀化.

左: JOA score は術前平均 53 点が術後 87 点に改善した。

疼找, 機能, ROM とも改善している。 


\section{- EMG-MUP 最大振幅（広背筋）-}

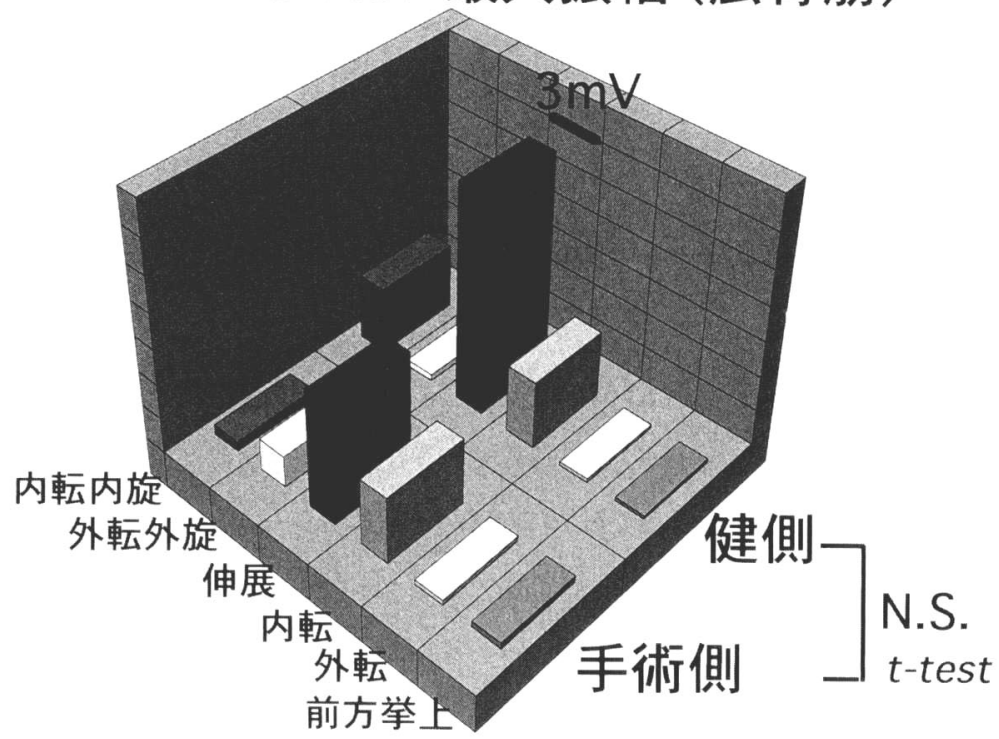

図 2 広背筋筋電図波型において MUP 最大振幅を計測し手術側，健側で比較した。手術 側は広背筋の本来の収縮方向である伸展, 内転内旋において振幅の減少を認めるが 有意差はない，外転外旋，前方拳上，外転においても有意差はない，

JOA 90 点である（図 3). 外転より前方拳上の方が 困難であるとの訴えがある．広背筋筋電図では伸展は 最大振幅 $1 \mathrm{mV}$ で健側の $70 \%$ に減少, 前方拳上と外 転時の motor unit potential は認められない。筋力 評価では求心性収縮筋力の健側比は前方拳上 $44 \%$, 外転 95\%と前方拳上で不良であった

\section{考}

広背筋の筋電図電気活動は Gerber ${ }^{2)}$ は 11 症例中前 方拳上 1 例, 外転 3 例, 外旋 7 例に認め大。.青木ら は 12 症例中 9 例に認め, 移行した広背筋が相乗的に 収縮していない 3 症例では成績が不良であったと述べ た. 今回の我々の険討では前方拳上 2 例, 外転 2 例, 外転外旋 3 症例に電気活動を認めたがその振幅は 50 から $300 \mu \mathrm{V}$ 程度で有意でなく，またその症例は JOA score 80 点, 82 点, 89 点で決して良好とは言え なかった，広背筋は特に伸展動作で強く収縮しており 術後に広背筋機能の switching は起こっていなかっ た. また switching がなくても成績とは無関係であ ると考えられた。
移行する広背筋はその収縮があれば前方拳上箭力を 增加させると期待されたが，実際には電気活動も有意 ではなく前方拳上筋力も健側の約半分で十分ではなかっ た. 前方拳上位での作業か涃難であるという愁訴む残っ ていた. 6 症例において deltopectoral approach で あったことが前方拳上筋力低下の一因と考え，今後は アプローチの工夫む考虑する必要がある，広背筋機能 の switching は起こらず，伸展動作で強く収縮した。 肩伸展時には広背筋縫合部は前方に引っ張られるのと 同時にその収縮により後方に引っ張られるため縫合部 に過度の緊張がかかり疼痛や再断裂の誘因となりうる。 労㗢に際して重量物を引っ張る作業には適していない，

$$
\text { ま と め }
$$

広背筋移行術を施行した 7 症例 7 肩関節の術後成績 を検討した，拳上角度は有意に改善し，内旋は 2 棘㔖 起ほど覀化する.JOA score は術後平均 87 点とほぼ 良好となる，筋電図による検討で広背筇の収縮は腱板 機能の補助とはなっていなかった。 


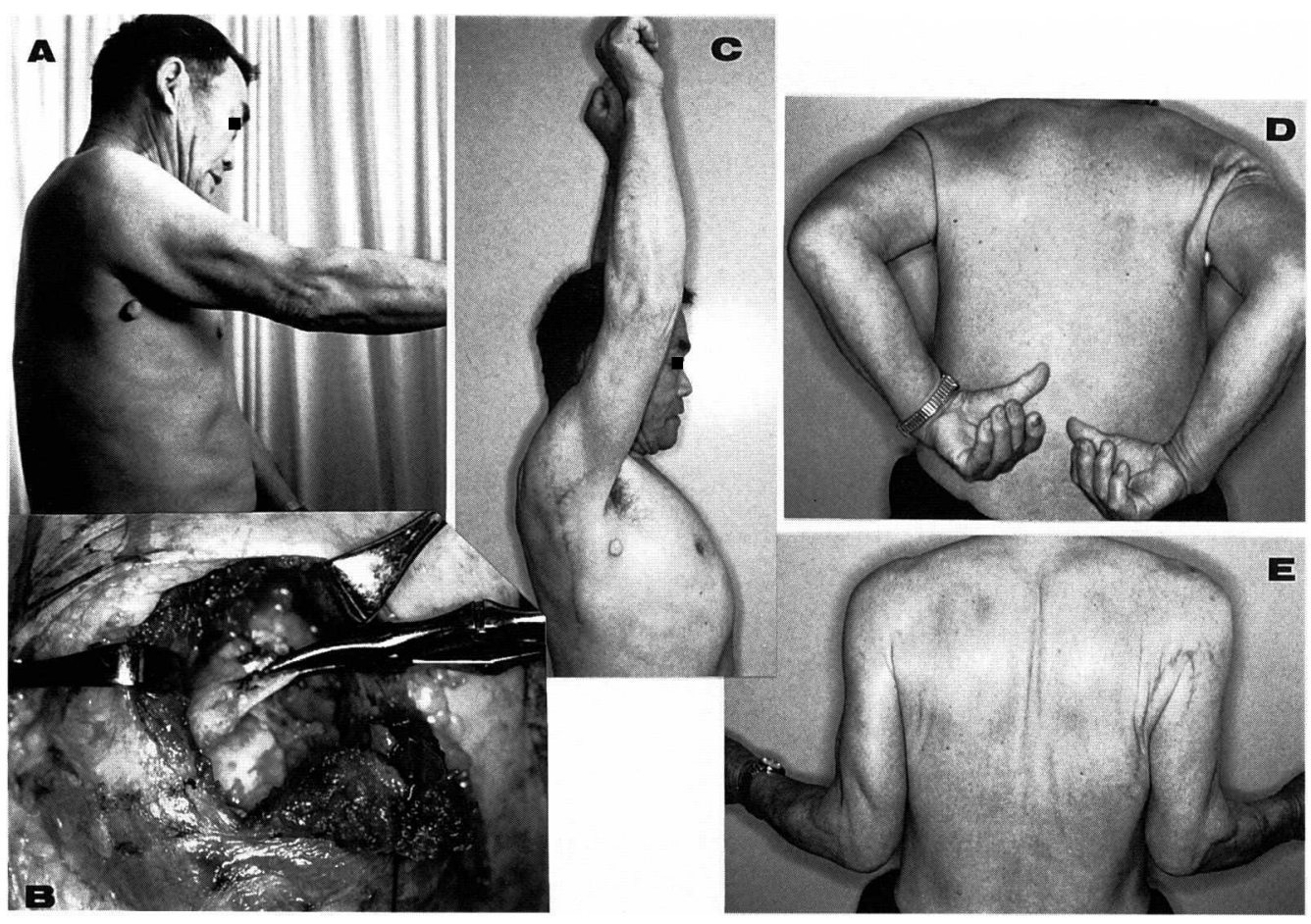

図 3 A : 術前 JOA56 点

B : 広背筋移行術

C, D, E : 術後 15 r月の前方拳上, 内旋, 外旋. JOA 90 点.

\section{参 考 文 献}

1) Aoki, M., et al. : Transfer of Latissimus Dorsi for Irrepable Rotator-Cuff Tears. JBJS., 78B : $761-766$,
1996.

2) Gerber, C. : Latissimus Dorsi Transfer for the Treatment of Irrepable Tears of the Rotator Cuff. Clin Orthop., $275: 152-159,1992$ 